\title{
Pemikiran Pendidikan Islam: Konseptualisasi Pendidikan Karakter Dalam Perspektif Intelektual Islam Klasik
}

Oleh:

Dwi Fitri Wiyono

Email: dwi.fitri@unisma.ac.id

Dosen Fakultas Agama Islam, Universitas Islam Malang

\begin{abstract}
Abstrak
Pendidikan karakter menempati posisi strategis dalam pendidikan Islam di Indonesia.dirasakan urgensitasnya untuk dirumuskan secara konseptual dalam perspektif Islam.Kajian pendidikan karakter dalam pemikiran tokoh-tokoh Islam klasik hingga modern selalu menjadi tema yang penting untuk dikaji dan dikembangkan didalam khazanah pendidikan Islam. Latar belakang yang mendasarinya antara lain, yakni: Pertama; pendidikan karakter merupakan tema penting yang menjadi perhatian pemangku kebijakan dalam merumuskan tujuan pendidikan. kedua; Pendidikan karakter menjadi dasar utama gagasan pemikiran pendidikan Islam. Ketiga; konsep dan pemikiran pendidikan karakter yang digagas oleh intelektual Islam klasikmemiliki persamaan dan perbedaan dengan konsep pendidikan yang berasal dari barat dan konsep pendidikan karakter yang diwariskan dari yunani kuno dan arab.
\end{abstract}

Kata Kunci: pemikiran pendidikan Islam, studi pendidikan karakter, intelektual Islam klasik. 


\begin{abstract}
Character education occupies a strategic position in Islamic education in Indonesia. its urgency is felt to be conceptually formulated in an Islamic perspective. The study of character education in the thinking of classical to modern Islamic figures has always been an important theme to be studied and developed in the treasury of Islamic education. The underlying background includes: First; character education is an important theme that is of concern to policy makers in formulating educational goals. second; Character education is the main basis for the idea of Islamic education. Third; the concept and thought of character education initiated by classical Islamic intellectuals have similarities and differences with the concept of education originating from the west and the concept of inherited character education from ancient Greece and Arabia.
\end{abstract}

Keywords: Islamic education thoughts, character education studies, classical Islamic intellectuals

\section{Pendahuluan}

Kajian pendidikan karakter dalam pemikiran tokoh-tokoh Islam klasik hingga modern selalu menjadi tema yang penting untuk dikaji dan dikembangkan didalam khazanah pendidikan Islam. Latar belakang yang mendasarinya antara lain, yakni: Pertama; pendidikan karakter merupakan tema penting yang menjadi perhatian pemangku kebijakan dalam merumuskan tujuan pendidikan, asumsinya adalah meningkatnya gejala dekadensi moral dikalangan remaja yang semakin terdegradasi dan menjadi fakta otentik dimedia massa akhir-akhir ini, kedua; Pendidikan karakter menjadi dasar utama gagasan dan pemikiran dalam bidang ekonomi, hukum, budaya, agama, sosial, dan yang paling utama adalah pendidikan Islam. Tokoh-tokoh Islam klasik yang akan dikaji pada bab ini diantarnya adalah: AlFarabi (w.339), Ibn Sina (980 M), Ibn Khaldun, Ibn Miskawaih (421 H), AlGhazali (1111 M), Ibn Taimiyah, Ibn Qayyim al-Jauziyah (1292 M), Syekh Ja'far al-Barzanji (1690 M), Tokoh-tokoh Islam klasik tersebut telah menulis gagasangagasan besar terhadap urgensitas pendidikan karakter. ${ }^{1}$ Ketiga; konsep dan

1 Abuddin Nata, Pendidikan Karakter dalam Wacana Intelektual Muslim dan Khazanah Dunia pemikiran pendidikan karakter yang digagas oleh tokoh-tokoh Islam klasikmemiliki persamaan dan perbedaan dengan konsep pendidikan yang berasal dari barat dan konsep pendidikan karakter yang diwariskan dari yunani kuno dan arab jahiliyah sebelum Islam turun ke jazirah arab. Keempat; Wacana kajian pendidikan Islam menempati posisi strategis dalam masalah pendidikan karakter, kondisi ini sejalan dengan substansi kajian pendidikan Islam yang secara filosofis tertuang dalam sumber-sumber hukum Islam yang mengedepankan konsep pendidikan karakter.

Dalam konteks problematika pendidikan Islam di Indonesia, persoalan mendasar yang dihadapi oleh pendidikan Islam selama ini adalah belum adanya temuan konsep dan format baku yang dijadikan rujukan oleh pemangku kebijakan pendidikan Islam (kementerian agama). Hal serupa dialami oleh negara lain dengan penduduk mayoritas umat Islam, khususnya di Negara-negara timur tengah. Kenyataan ini menunjukan lemahnya nalar pemikiran elit akademisi pendidikan Islam terutama dalam menterjemahkan

Pendidikan Islam, Makalah disampaikan pada pada acara seminar pendidikan berkarakter yang diselenggarakan oleh Institut Agama Islam (IAIN) Imam Bonjol, Padang tahun 2011. Hlm.2 
pemikirannya dari sisi aspek birokratteknokratik, sehingga bahan rujukan untuk pengembangan keilmuan pendidikan Islam ditataran grass root belum memiliki acuan baku maupun standart yang dimungkinkan internalisasi nilai-nilai maupun ideologi didalam suatu Negara terumuskan didalam konsep desain kurikulum dan menjadi rujukan dalam system kehidupan berbangsa dan bernegara dibidang Pendidikan Islam.

Persoalan pendidikan Islam diatas merupakan salah satu faktor mendasar lemahnya internalisasi pendidikan karakter yang menempatkan posisi strategis pendidikan Islam sebagai row material (bahan dasar) pondasi sendi-sendi kehidupan berbangsa dan bernegara.Pendidikan karakter di Indonesia dirasakan urgensitasnya untuk dirumuskan secara konseptual dalam perspektif Islam, mengingat saat ini terjadi intensitas dekadensimoral yang memprihatinkan khususnya dikalangan elit maupun masyarakat bawah.Bentuk-bentuk dekadensi moral diantaranya adalah budaya korupsi oleh pejabat tinggi, tawuran antar kelompok agama, etnis, ras, pelajar, bahkan dalam kompetisi olahraga, kekerasan bullying kerap menjadi tontonan sehari-hari di media social.Bangsa Indonesia yang dikenal dunia sebagai bangsa yang mengedepankan sopan santun dan hidup gotong royong dengan semboyan Bhineka Tunggal Ika tercederai oleh fakta-fakta yang jauh dari nilai-nilai luhur bangsa Indonesia das sein anddas sollen. Realitas ini semakin menunjukan urgensitasnya pendidikan Islam berwawasan karakter kebangsaan sebagai bentuk upaya preventif yang berdampak secara multidimensional dan sistematis.

\section{Konseptualisasi Tujuan Pendidikan Karakter}

Tujuan pendidikan merupakan penentu dasar suksesnya suatu proses pendidikan Islam, tujuan bukan hanya mentukan haluan yang dituju, tetapi sekaligus memberikan dasar stimulus untuk menggerakan keseluruan komponen pendidikan Islam. selain itu, tujuan pendidikan adalah internalisasi nilai-nilai (dipandang nilai) oleh peserta didik sebagai acuan tindakan moral yang menjadi mendorong dirinya untuk mengeluarkan segala daya dan upaya yang diperlukan untuk mencapai tujuan pendidikan. Tujuan pendidikan memiliki fungsi konsep dan praktis untuk memulai sebuah proses pendidikan Islam yang komprehensif.

Tujuan Pendidikan menurut tokohtokoh Islam klasik tidak hanya berorientasi pada individualitas peserta didik secara fungsional, akan tetapi pendidikan harus mampu dipraksiskan dalam kehidupan sehari-hari di masayarakat. Manifestasi pendidikan dalam konteks pendidikan karakter inilah yang tertuang dalam konsep tujuan pendidikan Islam pada aspek sosial dan kemasyarakatan.

Rumusan tujuan pendidikan pada hakikatnya merupakan rumusan filsafat atau pemikiran yang mendalam tentang pendidikan.Jika memahami secara filsafat, menurut al-Ghazali, pendidikan yang baikmerupakan jalan untuk mendekatkan diri kepada Allah SWT dan untuk mendapatkan kebahagiaan dunia akhirat. ${ }^{2} I b n$ Sina merumuskan tujuan

2 Abuddin Nata, Pemikiran Para Tokoh Pendidikan Islam, (Semarang: CV Asyifa'), Hlm143 
pendidikan Islam dengan konsep membentuk manusia yang berkepribadian akhlak mulia.Ibnu Sina kemudian menegaskan bahwa ukuran akhlak mulia yang dimaksud dijabarkan secara luas yang meliputi segala aspek kehidupan manusia.Aspek-aspek kehidupan manusia menjadi syarat bagi terwujudnya suatu sosok pribadi akblakul karimah yang meliputi aspek kepribadian, sosial, dan spiritual.Ketiganya harus berfungsi secara integral dan komprehensif.

Pembentukan akhlak mulia hakikatnya bertujuan untuk mencapai kebahagiaan sa'adah. Menurut Ibn Sina, kebahagiaan sa'adah dapat diperoleh manusia secara bertahap dari tujuan pendidikan yang berkenaan dengan budi pekerti, kesenian, dan perlunya keterampilan sesuai dengan bakat dan minat yang berkaitan erat dengan perkembangan jiwa seseorang. Hal ini menunjukan bahwa tujuan pendidikan akhlak spiritual mendapat penekanan yang lebih. $^{3}$

Selain penekanan pada aspek akhlak, tujuan pendidikan Islam menurut tokoh Islam klasik adalah untuk menyiapkan peserta didik dari segi kemasyarakatan atau sosial dan kesenian. Al-Syaibani menganalisis tujuan pendidikan menurut Ibn Khaldun, ada 6 (enam) tujuan pendidikan, yaitu: pertama; menyiapkan peserta didik dari sisi keagamaan dengan mengembangkan potensi iman, sebagaimana dengan potensi-potensi lain, kedua; menyiapkan peserta didik dari segi

3 Muhammad Iqbal, Pemikiran Pendidikan Islam, Gagasan-Gagasan Besar Ilmuwan Muslim, (Yogyakarta: Pustaka Pelajar, 2015). Hlm. 7 akhlak, ketiga; menyiapkan peserta didik dari segi social atau kemasyarakatan, keempat; menyiapkan peserta didik dari segi pekerjaan dan keterampilan vokasional, kelima; menyiapkan peserta didik dari segi nalar dan pemikiran, keenam; menyiapkan seseorang dari segi kesenian. ${ }^{4}$

Desain tujuan pendidikan Islam yang berdimensi sosial dan kemasyarakatan secara tekstual berdasarkan al-Qur'an dan al-Sunnah dirumuskan oleh tokoh Islam klasik lainnya yakni Ibn Taimiyah.Desain tujuan pendidikan yang digagas oleh Ibn Taimiyah tergambar pada pendidikan masyarakat Islam.Dasar pendidikan masyarakat Islam adalah menciptakan hubungan antar individu yang baik dalam sistem kemasyarakatan sesuai dengan yang dikehendaki oleh al-Qur'an dan alSunnah. ${ }^{5}$ Pada QS. Al-Maidah: 14, Ibn Taimiyah menafsirkan al-Hadz atau bagian dari risalah yang dilupakan oleh mereka itu adalah karena mereka lupa mempraktekan wahyu yang telah diberikan kepada nabi mereka dan hanya mengatakan aspek pendidikan individualnya saja tanpa merabah kepada persoalan hubungan social (masyarakat dan kebangsaan) yang akhirnya berakibat terjadinya permusuhan, kebencian dan perpecahan. Dengan demikian jelaslah bahwa pendidikan itu berproses dari pendidikan individual menuju social. ${ }^{6}$

\footnotetext{
${ }^{4}$ Muhammad Iqbal, Pemikiran Pendidikan Islam.... Hlm. 9

${ }^{5}$ Nurcholish Madjid, Islam Doktrin dan Peradaban (Jakarta: Yayasan wakaf Paramadina), Hlm. 138-139

${ }^{6}$ Muhammad Iqbal, Pemikiran Pendidikan Islam.... Hlm. 53
} 
Sedangkan metode pengajaran untuk mencapai tujuan pendidikan oleh Ibn Taimiyah bermuara pada aspek iradah, ini sesuai dengan konsep tiga ranah (kognitif, afekjtif, dan psikomotorik) yang dikembangkan oleh Benyamin S. Bloom yang selalu menjadi rujukan kurikulum dan tujuan pendidikan di Indonesia. ${ }^{7}$ Tujuan pendidikan yang menjurus kepada yang bersifat destruktif individu terhadap hubungan sistem kemasyarakatan, maka akan berdampak kepada kegagalan pendidikan Islam.

Tujuan pendidikan yang berdimensi pada akhlak sebenarnya tidak hanya dari aspek konsep praktis, seperti konsep beberapa tokoh Islam klasik diatas, aspek teoritis-filosofis menjadi perhatian penting orientasi strategis yang perlu dikonsepkan dalam mendesain tujuan pendidikan Islam, hal tersebut sebagaimana pemikiran Ibn Miskawaih tentang filsafat moral yang menaikan taraf kajian etika akhlak dari praktis ke teoritik-filosofis. ${ }^{8}$

Secara spesifik Syekh Ja'far alBarzanji, juga menterjemahkan tujuan pendidikan dalam bentuk syair-syair sastra yang tertuang dalam kitab al-Barzanji, diantaranya yakni pendidikan Islam memuat nilai-nilai akhlak, dimulai dengan kerendahan/ ketawadhu'an dari sang penyair, akhlak yang baik selalu membuat seseorang disekitarnya menjadi tenang, aman, dan terhindar dari perbuatan yang tercela. Seseorang yang berakhlak buruk menjadi sorotan bagi sesamanya, keluarga,

\footnotetext{
${ }^{7}$ Benyamin S. Bloom, Taxanomy of Educational Objectivitas, (New York: David Mckay Company, 1984), Hlm.7

${ }^{8}$ Suwito, Filsafat Pendidikan Akblak, Ibn Miskawaih, (Yogyakarta: Belukar 2004), Hlm.49
}

masyarakat, dan Negara. Diantara nilai-nilai akhlak dalam syair al-Barzanji, yakni: (a) akhlak dalam pergaulan. (b) akhlak terhadap anak (c) akhlak kepada Allah SWT. (d) akhlak kepada orang tua . (e) akhlak kepada profesi. (f) akhlak untuk selalu bermusyawarah. (g) akhlak terhadap orang yang telah mendholimi. (h) akhlak terhadap keluarga. (i) akhlak terhadap orang lemah. (j) akhlak dalam kemarahan. ${ }^{9}$

\section{Konseptualisasi Kurikulum Pendidikan Karakter}

Para tokoh Islam klasik dalam mendesain konsep kurikulum pendidikan Islam terdapat perbedaan, hal ini menurut hemat penulis karena banyak dipengaruhi oleh landasan filosofis dalam memahami hakikat keberadaan dan perkembangan manusia. Meskipun demikian, penulis menganalisis dan mendapati beberapa persamaan dalam menentukan kurikulum yang sesuai dengan kebutuhan manusia (peserta didik), salah satu persamaannya adalah seluruh komponen pendidikan yang digagas oleh tokoh-tokoh Islam klasik menekankan pada pentingnya dimensi akhlak dalam mewujudkan suksesnya suatu proses pendidikan Islam.

Akhlak menjadi tema sentral dalam kurikulum yang digagas oleh tokoh-tokoh Islam klasik. Jika dikaitkan dengan kurikulum berwawasan karakter kebangsaan, kurikulum pendidikan Islam harus mempertimbangkan aspek output dan outcome yang berorientasi pada aktualisasi

9 Muhammad Iqbal, Pemikiran Pendidikan Islam, Gagasan-Gagasan Besar Ilmuwan Muslim, (Yogyakarta: Pustaka Pelajar, 2015). Hlm. 459 
diri dalam kehidupan masyarakat dan entitas yuridis (kebangsaan). Kurikulum harus bersifat fungsional-pragmatis, yakni sesuai dengan nilai guna dan kebutuhan masyarakat.Hal ini dapat dilihat dari setting bistoris yang mendorong tokoh-tokoh Islam klasik dalam mengekspresikan pemikirannya di bidang pendidikan Islam.

Menurut Ibn Sina, Pelajaran akhlak dan budi pekerti atau diera sekarang dikenal dengan pendidikan karakter diarahkan untuk membekali peserta didik agar memiliki kebiasaan sopan santun dalam pergaulan hidup sehari-hari. Pelajaran budi pekerti ini sangat dibutuhkan dalam rangka membina kepribadian peserta didik sehingga jiwanya menjadi suci dan terhindar dari perbuatanperbuatan tercela yang dapat mengakibatkan jiwanya rusak dan sulit diperbaiki. Imam al-Zarnuji dalam karya monumentalnya Ta'lim al-Muta'lim alTa'allun lebih detail membahas tentang pentingnya akhlak, terutama tentang akhlak peserta didik dan pendidik dalam proses pendidikan Islam. ${ }^{10} \mathrm{Kitab}$ Ta'lim alMuta'allim karya Imam al-Zarnuji ini banyak dikaji dan dipelajari hampir disetiap lembaga pendidikan Islam terutama pondok pesantren di Indonesia.Kurikulum pendidikan Islam perlu dikembangkan dalam konteks pembelajaran dalam jangka waktu yang lama (bertahap dan berjenjang) tidak parsial.Problem inilah yang menjadi penyebab ketertinggalan pendidikan di Indonesia.Ada kecenderungan setiap ganti pemerintahan berganti pula kurikulum yang diberlakukan. Kondisi ini akan

10 Muhammad Iqbal, Pemikiran Pendidikan Islam, Gagasan-Gagasan Besar Ilmuwan Muslim... Hlm. 379 melemahkan gagasan penguatan pendidikan karakter kebangsaan yang terus menerus berubah seiring bergantinya political will pemimpin pemerintahan dan negara.

\section{Konseptualisasi Metode Pendidikan Karakter Kebangsaan}

Syekh Ja'far bin Hasan al-Barzanji mengungkapkan bahwa karya sastra selalu memberikan pesan atau amanah untuk berbuat baik, dan masyarakat atau pembaca diajak untuk menjunjung tinggi normanorma moral. ${ }^{11}$ Dengan cara yang berbeda sastra dan agama dianggap sebagai sarana untuk menumbuhkan jiwa kemanusiaan yang halus dan berbudaya. ${ }^{12}$ Melalui karya sastra ini pula metode pendidikan Islam dirumuskan oleh Syekh Ja'far bin Hasan alBarzanji dalam kitab al-Barzanji untuk menanamkan nilai-nilai etika, moral, dan pandangan hidup dipribumisasikan dengan basis fundamentalis sosial-budaya masyarakat berdasarkan sejarah atau riwayat hidup nabi Muhammad SAW.

Karya sastrawan Syekh al-Barzanji berupa kitab al-Barzanji yang memuat hal keagungan rashulullah sebagai suri tauladan umat manusia, kiranya menjadi contoh konsep metode pendidikan yang berupa syair-syair sastra seperti dakwah yang dilakukan oleh wali songo metode pendidikan Islam melalui syair sastra akan

11 Muhammad Iqbal, Pemikiran Pendidikan Islam, Gagasan-Gagasan Besar Ilmuwan Muslim, (Yogyakarta: Pustaka Pelajar, 2015). Hlm. 430

12 Wardiman Djoyonegoro, Peningkatan Kualitas SDM Melalui Pendidikan dan Kebudayaan, (Jakarta: Departemen Pendidikan dan Kebudayaan), Hlm. 201. 
mampu menggugah kesadaran peserta didik dalam internalisasi karakter kebangsaan di Indonesia, dalam catatan sejarah pemikiran modern Islam, hal serupa pernah dilakukan oleh Muhammad Iqbal di India, melaui syair-syairnya mampu menggelorakan semangat bangkitnya kesadaran ketertindasan imat Islam India yang kemudian hari menjadi embrio lahirnya komunitas Islam Islamic Nation State yang diberi namaNegara Islam Pakistan.

Relitas pendidikan Islam di Indonesia selama ini, metode yang digunakan terbatas pada aspek kognitif (hafalan), meskipun dimensi afektif menjadi salah satu komponen tujuan pendidikan dalam kurikulum, akan tetapi metode pengajaran masih tetap menekankan aspek kognitif. Metode olah rasa melalui syair akan lebih menggugah kesadaran peserta didik dalam meningkatkan jiwa nasionalisme dan darakter kebangsaan yang kokoh dan tangguh.

\section{Konseptualisasi Pendidik dan Peserta Didik Berkarakter}

Menurut Al-Ghazali, pendidik dalam pegertian akademik ialah seseorang yang menyampaikan sesuatu kepada orang lain atau seseorang yang menyertai sesuatu institusi untuk menyampaikan ilmu pengetahuan kepada para pelajarnya. ${ }^{13}$ Dalam pengertian lain Pendidik menurut al-Ghazali adalah setiap orang yang dengan sengaja mempengaruhi orang lain untuk

${ }^{13}$ Imam Tolkhah, Membuka Jendela Pendidikan Mengurai Akar Tradisi dan Integrasi Keilmuan Pendidikan Islam, (Jakarta: Grafindo Persada, 2004), Hlm.263 mencapai kedewasaan. ${ }^{14}$ Ibn Qayyim menyebut pendidik dengan sebutan alim rabbani, Pendidik merupakan salah satu komponen pendidikan Islam yang sangat penting dalam mewujudkan tujuan pendidikan Islam, hal ini diungkapkan oleh Wan Daud yang menyatakan bahwa peranan pendidik dianggap sangat penting, peserta didik disarankan untuk tidak tergesa-gesa memilih belajar kepada pendidik yang kurang memiliki kredibilitas dalam menyampaikan materi pelajaran, sebaiknya peserta didik, melalui orang tua mencari siapa pendidik terbaik dalam bidang tertentu dan harus disukai oleh peserta didik.

Aspek diatas digambarkan oleh oleh Syekh Ja'far bin Hasan al-Barzanji dalam kitab syair al-Barzanji yang dilukiskan tentang kehidupan Rasulullah dalam asuhan Siti Aminah yang kemudian diserahkan kepada Khalimah Sa'diyah untuk mengasuh, merawat dan mendidik Rasulullah SAW. ${ }^{15} \mathrm{Kitab}$ al-Barzanji merupakan kitab yang dikarang oleh Ja'far al-Barzanji, lahir didaerah Barzinj (Kurdistan) merupakan karya sastra dengan syair-syair yang indah dan sudah ratusan tahun dipakai, namun belum ada yang menandingi karya sastra tersebut.Selain itu kiranya learning experience atau pengalaman belajar pendidik juga berpretensi positif dalam merangsang kesadaran dan komitmen peserta didik mengenai masalah sosial dan etika kemasyarakatan.

${ }^{14}$ Hery Noer Aly, Ilmu Pendidikan Islam, (Jakarta: Logos, 1999), Hlm.81

${ }^{15}$ Wan Moh. Wan Daud, Filsafat dan Praktik Pendidikan Islam Muhammad Naquib Al-Attas, (Bandung: Mizan Media Utama, 2008), Hlm.261 
Kompetensi profesional dari seorang pendidik menjadi perhatian serius al-Ghazali dalam mendidik peserta didik.Untuk menjadi pendidik profesional, Imam Al-Ghazali menetapkan kriteria umum yakni, cerdas dan sempurna akalnya, baik akhlaknya, dan kuat fisiknya. Selain kriteria umum yang harus dimiliki pendidik, menurut Imam Al-Ghazali, ada sisfat-sifat khusus dan tugas-tugas tertentu, yakni: Pertama, Rasa kasih sayang terhadap peserta didik; Kedua, pendidik adalah kewajiban seorang yang berilmu; Ketiga, Pendidik adalah seorang pengarah dan penyuluh yang jujur dan benar dihadapan peserta didiknya; Keempat, Pendidik harus tampil sebagai teladan dan panutan yang baik bagi peserta didik; Kelima, Pendidik hendaknya menggunakan cara (metode) yang simpatik; Keenam, Pendidik harus memiliki prinsip adanya perbedaan potensi yang dimiliki peserta didik; Ketujuh, pendidik harus berpegang teguh pada prinsip yang diucapkan.

Sementara itu mengenai peserta didik, Ibn Qayyim al-Jauziyyah menyebutnya dengan istilah mu'alim, menurut Ibn Qayyim al-Jauziyyah, mu'allim adalah peserta didik yang mencari ilmu demi mendapatkan keselamatan dirinya sendiri. ${ }^{16}$ Tokoh Islam seperti ini ikhlas dalam menuntut ilmu. Diantara akhlak seorang peserta didik, yakni: ${ }^{17} \quad$ (a) hendaklah peserta didik menjauhi kemaksiaatan dan senantiasa menundukan pandangan dari hal-hal yang diharamkan

${ }^{16}$ Ibn. Qayyim Al-Jauziyah, Miftah Dar asSa'adah, terj. Abdul Matin, (Solo: Tiga Serangkai, 2009), Hlm.283

${ }^{17}$ Ibn. Qayyim Al-Jauziyah, Miftah Dar asSa'adah...Hlm.284 untuk dipandang. (b) hendaklah para peserta didik mewaspadai tempat-tempat yang menyebarkan Labwun (kesia-siakan) dan majelis-majleis keburukan.(c) hendaklah peserta didik senantiasa menjaga waktunya (d) janganlah sekali-kali mengatakan sesuatu yang tidak memiliki ilmu (e) hendaklah peserta didik menjaga ilmunya (e) hendaklah diketahui oleh peserta didik bahwa dengan ilmu peserta didik tidak akan memperoleh derajat tertinggi kecuali ilmunya diamalkan.

Adapun adab peserta didik terhadap pendidik menurut Ibn Qayyim alJauziyyah diantaranya adalah: ${ }^{18}$ (a) peserta didik hendaklah selalu mularamah (menyertai) pendidik berusaha mengambil faedah darinya. (b) peserta didik jika sudah mulazamah, hendaknya ia senantiasa menuruti nasehat dan petunjuk pendidik. (c) Wajib seorang peserta didik melembutkan suaranya ketika bertanya dan tidak mendebat secara berlebihan.

Ada beberapa hal yang perlu digaris bawahi dalam dinamika akademik dan relasi antara pendidik dan peserta didik, sebagaimana dituangkan dalam $T$ a'lim alMuta'alim, persyaratan dalam mencari ilmu demi mendapat kesuksesan dituangkan dalam syairnya, tidak akan berhasil seseorang dalam mencari ilmu kecuali dengan enam syarat, yakni: ${ }^{19}$ cerdas, rasa ungin tahu yang tinggi, sabar, mempunyai biaya, adanya petunjuk dari pendidik, waktu yang lama. konsep terakhir yang dikemukanan al-Zarnuji ini sesuai dengan

${ }^{18} \mathrm{Ibn}$. Qayyim Al-Jauziyah, Miftah Dar asSa'adah...Hlm.286

${ }^{19}$ Syekh Ibrahim bin Ismail al-Zarnuji, Ta'limul Muta'alim, (Semarang: CV.Toha Putera), HLm.16 
pendidikan karakter bangsa Indonesia yang harus dimiliki oleh peserta didik dalam menumbuhkan karakter kebangsaan yang kokoh dan tangguh.

\section{Konsep Integrasi Pendidikan Karakter, Negara dan Masyarakat}

Menurut Al-Farabi, Manusia merupakan makhluk sosial yang tidak mungkin hidup sendiri-sendiri. Manusia hidup bermasyarakat dan saling tolong menolong untuk kepentingan bersama dalam mencapai tujuan hidup yakni kebahagiaan. ${ }^{20}$ Sifat dasar inilah yang mendorong manusia hidup bermasyarakat dan bernegara. Konsep masyarakat menurutnya terbagi menjadi dua macam, Pertama; masyarakat sempurna, dikatakan sempurna karena masyarakat kategori kelompok besar, bisa dalam bentuk masyarakat perkotaan maupun masyarakat yang terdiri dari beberapa bangsa yang bersatu dan bekerja sama secara global. Kedua; Masyarakat tidak sempurna adalah masyarakat dalam satu keluarga atau masyarakat wilayah desa, masyarakat terbaik adalah masyarakat yang bekerjasama, saling tolong menolong untuk mencapai kebahagiaan.Masyarakat ini disebut masyarakat utama.

Al-Farabi membagi Negara atau pemerintah menjadi Negara (kota) utama al-madinah al-fadbilah, negara jahil al-madinah al-jabilah, Negara sesat al-madinah al-dhalah, Negara fasik al-madinah al-fasiqah, dan negara berubah al-madinah al-

20 Asep Sulaiman, Mengenal Filsafat Islam, (Bandung: Yrama Widya, 2016). Hlm.38 mutabadillab. ${ }^{21}$ Negara Utama, sebagai satu masyarakat yang sempurna al-mujtami' alkamilah, dalam arti masyarakat yang sudah lengkap bagian-bagiannya, oleh al-Farabi disebut sebagai organisme tubuh manusia dengan anggota yang lengkap. ${ }^{22}$ Masingmasing organ tubuh harus bekerja sesuai dengan fungsinya.Anggota masyarakat Negara utama, yang terdiri dari warga yang berbeda kemampuan dan fungsinya, hidup saling membantu, masing-masing diberikan pekerjaan yang sesuai dengan spesialisasi mereka. Fungsi utama dari pemikiran alFarabi adalah tentang kepala Negara yang serupa dengan fungsi jantung didalam tubuh manusia. Kepala Negara merupakan sumber seluruh aktifitas, sumber peraturan, dan keselarasan hidup dalam masyarakat. ${ }^{23}$

Konsep al-Farabi tentang Negara dan masyarakat menekankan pada fungsi kepala Negara sebagai posisi sentral dalam kehidupan berbangsa dan bernegara. Konsep diatas memiliki kesamaan dengan konsep Negara utama yang digagas oleh Ibn Bajjah, meskipun ada beberapa perbedaan dengan al-Farabi, Warga Negara utama menurut Ibnu Bajjah, masyarakat tidak lagi memerlukan dokter atau hakim. sebab mereka hidup dalam keadaan puas terhadap rezeki yang diberikan Allah yang dalam istilah agama disebut al-qana'ah. mereka yang tidak mau memakan makanan yang akan merusak kesehatan.

\footnotetext{
${ }^{21}$ Asep Sulaiman, Mengenal Filsafat Islam...Hlm.39

22 Sirajuddin Zar, Filsafat Islam, Filosof dan Filsafatnya, Jakarta: PT Raja Gravindo Persada, 2014). Hlm. 84-89

23 Sirajuddin Zar, Filsafat Islam, Filosof dan Filsafatnya...Hlm. 84-89
} 
Menurut Ibn Khaldun, pengembangan pendidikan Islam harus membentuk pola pikir relatifistiktemporalistik-materialistik, dengan pola pikir seperti itu, Ibn Khaldun mengamati dan menganalisa gejala-gejala sosial beserta sejarahnya, yang pada akhirnya tercipta suatu teori kemasyarakatan yang modern, kaitannya dengan konsep filosofis pendidikan Islam, Ibn Khaldun tidak ingin terjebak pada pemikiran konservatif, bahwa pencarian ilmu pengetahuan dalam pendidikan Islam tidak hanya hasil pengamatan inderawi dan nalar akal pikiran manusia, melainkan akan terwujud dengan mengedepankan watak kebudayaan culture oriented. Sebab, akal pikir adalah sarana manusia memperoleh kehidupan, saling berinteraksi antar sesama dan kemasyarakatan secara kohesif dan dinamis akan mewujudkan konsep idealitas pendidikan karakter dalam konteks kehidupan kemasyarakatan. ${ }^{24}$

\section{Kontekstualisasi Konsep Pendidikan Karakter dalam berkebangsaan Di Indonesia}

The founding fathers Republik Indonesia, Ir. Soekarno, menyatakan bahwa Bangsa ini harus dibangun dengan mendahulukan pembangunan karakter character building, karena karakter inilah, bangsa Indonesia akan menjadi bangsa yang maju, jaya, dan bermartabat. Jika karakter tidak dibangun sejak dini, maka bangsa Indonesia akan menjadi bangsa budak. Di Indonesia pelaksanaan

24 Muhammad Jawwad Ridla, Tiga Aliran Utama Teori Pendidikan Islam: Perspektif SosiologisFilosofis, (Yogyakarta: Tiara Wacana, 2002), Hlm.191-194 pendidikan karakter kebangsaan saat ini memang dirasakan mendesak.Gambaran situasi masyarakat, bahkan situasi pendidikan Islam di Indonesia menjadi motivasi pokok pengarusutamaan mainstreaming implementasi pendidikan karakter berwawasan kebangsaan.

Pendidikan Islam sebagai core advantage dalam mempersiapkan kekuatan karakter kebangsaan perlu digagas secara konseptual sejak dini. Keyakinan ini juga menjadi pondasi dasar bagi kacamata dunia untuk mengatakan bahwa bangsa Indonesia merupakan bangsa yang kuat disemua sektor, gambaran kondisi ini, oleh Fathur Rokhman diprediksi dalam penelitiannya pada tahun 2045 atau 100 tahun setelah Indonesia merdeka akan menjadi Negara yang berkarakter kuat diberbagai lini. Kondisi ini didukung oleh pertumbuhan ekonomi terbesar ke-16 di dunia. ${ }^{25}$ Indonesia memiliki potensi untuk menjadi Negara ke-7 (G7) pada tahun 2030.Dalam konteks ini, bangsa Indonesia perlu mempersiapkan generasi muda menyambut Bonus Demografi tabun 20252035.Penguatan karakter berwawasan kebangsaan melalui pengembangan konsep praktis pendidikan Islam di Indonesia menjadi jalan satu-satunya untuk menjadi bangsa yang kuat pada tahun $2045 .^{26}$

${ }^{25}$ Fathur Rokhman dkk, Character education for Golden Generation 2045 (National Caracter Building for Indonesian Golden Years), Semarang State University: Procedia, Social and Behavioral Sciences 141 (2014) 1161-1165.

${ }^{26}$ Fathur Rokhman dkk, Character education for Golden Generation 2045(National Caracter Building for Indonesian Golden Years), Semarang State University: Procedia, Social and Behavioral Sciences 141 (2014) 1161-1165. 
Program Penguatan Pendidikan Karakter (PPK) yang digagas oleh kementerian Pendidikan dan Kebudayaan Republik Indonesia yang kemudian direvisi melalui Peraturan Presiden Nomor 87 Tahun 2017 merupakan aspek yuridis dari kebijakan pemerintah yang bisa dikontekstualisasikan dengan konsep pendidikan karakter tokoh-tokoh Islam klasik. Dalam konteks pendidikan di Indonesia, nilai-nilai karakter bangsa Indonesia terdapat 18 karakter yang wajib dimiliki oleh peserta didik diantaranya adalah religius, jujur, toleransi, disiplin, kerja keras, kreatif, mandiri demokratis, rasa ingin tahu, semangat kebangsaan, prestasi, cinta damai, membaca, komunikatif, peduli lingkungan, peduli social dan tanggung jawab. Salah satu dari 18 karakter tersebut dibahas oleh Ibnu Sina dalam mendesain konsep kurikulum menempatkan karakter kepedulian lingkungan harus dimulai sejak dini yakni usia 3-5 tahun masa perkembangan peserta didik. Konsep pendidikan cinta lingkungan bertujuan menjadikan anak memiliki kebiasaan mencintai kebersihan yang juga menjadi salah satu ajaran mulia dalam Islam. Ibn Sina merupakan tokoh ulama' klasik yang merumuskan kurikulum berdasarkan tingkat perkembangan usia peserta didik, dimana konsentrasi pendidikan akhlak, cinta kebersihan lingkungan, dan budi pekerti melalui seni ditempatkan pada usia awal (usia balita), sebelum peserta didik memperoleh pengetahuan keterampilan. ${ }^{27}$

27 Abuddin Nata, Pemikiran Para Tokoh Pendidikan Islam, Suatu Kajian Filsafat Pendidikan Islam, (Jakarta: PT. Raja Grafindo Persada, 2003), Hlm.71-73

\section{Penutup}

Pada bagian akhir tentang konseptualisasi pendidikan karakter kebangsaan ini, penulis menyimpulkan ada beberapa hal mendasar yang perlu dikoreksi dari implementasi pendidikan Islam di Indonesia sebagai upaya kontekstualisasi penguatan pendidikan karakter diantaranya sebagai berikut:

Pertama, Pendidikan akhlak sistematis-integralistik, dari uraian tokohtokoh ulama' klasik diatas, konsep pendidikan karakter dalam pendidikan Islam perlu dirumuskan secara sistematis dan gradual, antara kurikulum pendidikan usia dini, tingkat dasar, menengah dan perguruan tinggi sebagaimana kurikulum yang dirumuskan oleh Ibnu Sina yang mengacu pada tingkat perkembangan peserta didik. Mulai usia 3-5 tahun hingga usia 14 tahun keatas. Konsep dan metode pentahapan pendidikan Islam juga ditegaskan oleh Ibn Khaldun dalam metode pengajaran yang disebut dengan Tadarrij.Pendidikan akhlak atau pendidikan karakter tidak hanya terpaku pada individualitas diri peserta didik tapi terintegrasi dalam nilai-nilai kehidupan social sebagai satu entitas masyarakat berbangsa dan bernegara.

Kedua, Pendidikan berkesadaran jiwa al-nafs, tujuan pendidikan di Indonesia terlalu menekankan pada aspek material, hanya berorientasi pada keterampilan dan individualitas religious, kurang menyentuh pada dimensia kesadaran jiwa al-nafs. Kecerdasan jiwa perlu menjadi perhatian penting didalam menentukan tujuan pendidikan Islam dengan menggunakan metode dan pendekatan penyucian jiwa 
tazkiyah al-nafs, proses pembelajaran dalam pendidikan Islam selain menggunakan model integralistik perlu metode penyucian jiwa, materi pembelajaran tasawuf secara praksis harus mampu menjadi pondasi dan membuka kesadaran peserta didik akan pentingnya aktualisasi hidup yang berkarakter yang secara teks sumber hukum Islam mengatur tentang hal tersebut.

Ketiga; Pendidikan berorientasi pada karakter sosial-kemasyarakatan, Tujuan Pendidikan tidak hanya berorientasi pada individualitas peserta didik secara fungsional, akan tetapi mampu dipraksiskan dalam kehidupan sehari-hari di masayarakat. Konseptualisasi pendidikan karakter kebangsaan, oleh para tokoh Islam klasik termanifestasikan dalam konsep tujuan pendidikan Islam yang menekankan pada aspek sosial atau kemasyarakatan.

Konseptualisasi pendidikan karakter dapat dirumuskan dengan model internalisasi nilai-nilai karakter yang bersumber dari alqur'an dan hadits yang digagas oleh tokoh-tokoh intelektual klasik kedalam muatan kurikulum yang berlaku pada setiap satuan pendidikan (KTSP/kurikulum 2013). Setiap pemangku mata pelajaran diharuskan untuk mengembangkan penanaman pendidikan karakter berdasarkan nilai-nilai ideologis, filosofis, agama, budaya, dan kepribadian luhur bangsa Indonesia.

\section{Daftar Pustaka}

Al-Jauziyah, Ibn. Qayyim, Miftah Dar asSa'adah, terj. Abdul Matin, (Solo: Tiga Serangkai, 2009)

Aly, Hery Noer Ilmu Pendidikan Islam, (Jakarta: Logos, 1999)

Bloom, Benyamin S, Taxanomy of Educational Objectivitas, (New York: David Mckay Company, 1984)

E. Mulyasa, Manajemen Pendidikan Karakter, (Jakarta: Bumi Aksara, 2014)

Iqbal, Abu Muhammad, Pemikiran Pendidikan Islam, (Yogyakarta: Pustaka Pelajar, 2015)

Maemonah, Reward and Punishment Sebagai Metode Pendidikan Anak Menurut Ulama' Klasike (Studi Pemikiran Ibnu Miskawaih, al-Ghazali dan al-Zarnuji, (Semarang: Tesis Program Pasca Sarjana IAIN Walosongo, 2009)

Madjid, Nurcholish, Islam Doktrin dan Peradaban (Jakarta: Yayasan wakaf Paramadina)

Nashir, Haedar, Pendidikan Karakter Berbasis Agama dan Budaya, (Yogyakarta: Multi Presindo, 2013)

Nata, Abuddin, Pendidikan Karakter dalam Wacana Intelektual Muslim dan Khazanah Dunia Pendidikan Islam, Makalah Seminar, Institut Agama Islam (IAIN) Imam Bonjol, Padang tahun 2011

Rokhman, Fathur dkk, Character education for Golden Generation 2045 (National Caracter Building for Indonesian Golden Years), (Semarang State University: Procedia, Social and Behavioral Sciences, 2014)

Samani, Muchlas, Konsep dan Model Pendidikan Karakter, (Bandung: PT. Remaja Rosdakarya, 2014)

Shoimin, Aris, Guru Berkarakter: Untuk Implementasi Pendidikan Karakter, (Yogyakarta: Gavamedia, 2014) 
Nidhomul Haq, Vol 2 No 3 Tahun 2017

Sonhaji, Ahmad, Membangun Peradaban Bangsa dalam Perspektif Multikultural, (Malang: UM Press, 2015)

Sulaiman, Asep, Mengenal Filsafat Islam, (Bandung: Penerbit Yrama Widya, 2016)

Suwito, Filsafat Pendidikan Akblak, Ibn Miskawaih, (Yogyakarta: Belukar, 2004)

Tolkhah, Imam, Membuka Jendela Pendidikan Mengurai Akar Tradisi dan Integrasi Keilmuan Pendidikan Islam, (Jakarta: Grafindo Persada, 2004)

Zar, Sirajuddin, Filsafat Islam: Filosof dan Filsafatnya, (Depok: PT.

Rajagrafindo Persada, 2014) 